DOI 10.17150/978-5-7253-3001-4.20

В.М. ЛЕВЧЕНКО

УДК 331.108.45:631(571.5)(09)

ББК 65.24:4(253.5)г

\title{
КАДРЫ МАССОВЫХ ПРОФЕССИЙ \\ В АГРАРНОМ СЕКТОРЕ ЭКОНОМИКИ ВОСТОЧНОЙ СИБИРИ (1965-1970)
}

Рассматриваются вопросы подготовки и повышения квалификации кадров массовых профессий: механизаторов и животноводов, мероприятия по их закреплению на селе.

Ключевые слова: Восточная Сибирь, колхозы и совхозы, механизаторы и животноводы. 


\section{CADRES OF MASS OCCUPATIONS IN THE AGRARIAN SECTOR OF THE ECONOMY OF EASTERN SIBERIA (1965-1970)}

The issues of training and raising the level of skill of the personnel of mass professions are considered: machine operators and cattle breeders, measures for their fixation in the village.

Keywords: Eastern Siberia, collective and state farms, machine operators and livestock breeders.

Актуальность вынесенной в заголовок темы с точки зрения сегодняшней организации агропромышленного комплекса России в целом и Восточной Сибири, в частности, может быть дискуссионной, но в условиях общественной организации и ведения хозяйства она несомненна.

Рассматривая ее в контексте экономических реформ 1960-х гг. прошлого столетия, затронувших практически все отрасли народного хозяйства, необходимо отметить, что касательно аграрного сектора - это время значительного увеличения капитальных вложений в сельскохозяйственное производство. В годы восьмой пятилетки они (без колхозов) почти на 32 \% превышали капиталовложения в седьмой пятилетке и превосходили вложения, осуществленные в годы шестой и седьмой пятилетки вместе взятые. Мы уже отмечали что принятые меры позволили увеличить производство и поставку селу тракторов, зерноуборочных комбайнов, машин и современного оборудования для животноводческих ферм, мелиоративной и другой техники.

За период 1966-1970 гг. парк тракторов в совхозах и колхозах Восточной Сибири увеличился на 8,9 тыс. единиц, а зерноуборочных комбайнов на 3,8 тыс. Произошло не только количественное, но и качественное его обновление. Были созданы и поступили в сельское хозяйство мощные трактора Т-4м, Т-130, К-700, новые высокопроизводительные зерноуборочные комбайны «Нива», «Колос», «Сибиряк».

Рост капиталовложений сказался и на материально-технической базе животноводства. Так, например, в Тулунском районе Иркутской области было введено в эксплуатацию 20 коровников на 5200 голов крупного рогатого скота, 11 свиноферм на 11100 голов и 17 телятников на 52000 скотомест. В колхозах и совхозах Красноярского края были построены животноводческие помещения на 222 тыс. голов овец.

Наряду с этим был осуществлен значительный объем работ по электрификации сельского хозяйства. Так, в Красноярском крае к 1970 г. отпуск электроэнергии на производственные нужды по сравнению с 1965 г. вырос в два раза. В Иркутской области в 1969 г. Все колхозы и совхозы были электрифицированы. 
Произошедшие перемены отразились на повышении фондовооруженности труда. В Бурятской АССР в 1970 г. на одного сельскохозяйственного работника приходилось 4,1 тыс. р. основных фрондов против 2,7 тыс. р. в 1965 г. [8, с. 260-261].

Насыщение сельскохозяйственного производства Восточной Сибири машинами и механизмами, расширение использования электроэнергии создали предпосылки для механизации производственных процессов в земледелии и животноводстве.

Для этого нужны были люди. Механизатор стал центральной фригурой на селе. От его профессионального умения, самоотверженности в работе в первую очередь зависела эфрфективность использования сельскохозяйственной техники, равно как и продуктивность растениеводства и животноводства. И еще одно обстоятельство в этой связи. Промышленное развитие региона, новые стройки и города также нуждались в квалифицированных рабочих руках и эти потребности в значительной мере удовлетворялись за счет сибирского села. Отсюда отток кадров из сельского хозяйства и задача закрепления их на селе.

Механизаторов широкого профиля готовили сельские профессионально-технические училища (СПТУ). В рассматриваемый период времени обозначилась тенденция к расширению сети сельского профрессионального технического образования, к росту численности обучающихся. Если в 1969 г. в Красноярском крае действовало 24 училища и 53 их фрилиала, то уже в 1970 г. в крае было 24 училища и 90 их фрилиалов в которых обучалось 8135 человека [9, д. 24, л. 154]. В училищах Иркутской области за период 1966-1969 гг. при плане 9310 человек было подготовлено 9780 трактористов-машинистов [6, л. 14].

Но таким положение было не везде. Противоположная ситуация сложилась в Бурятской АССР. Например, в 1968 г. в хозяйствах Еравнинского района для проведения весенне-полевых работ не хватало 412 трактористов, Баргузинского - 238, Селенгинского - 110 человек. Несмотря на это подготовка механизаторских кадров в этих районах велась неудовлетворительно. Крайне мало направлялось колхозников и рабочих совхозов на учебу в профтехучилища. Так, в Еравнинском районе в 1967 г. на учебу было направлено всего 22 человека. Все это явилось следствием того, что прирост количества тракторов и комбайнов в республике составил в 1968 г. по отношению к 1963 г. 41 \%, а рост численности кадров механизаторов - только 23 \% [4, д. 93, л. 27]. Это вело к нерациональному и малопроизводительному использованию имеющейся техники, простою. Все это стало предметом обсуждения на бюро обкома КПСС в январе 1968 г. Во исполнении принятого тогда постановления в республике на 1 фревраля 1968 г. на курсы подготовки механизаторов было направлено 683 человека, а на курсы повышения квалификации 1245 механизаторов. Дополнительно было организовано 
18 кружков для подготовки 337 механизаторов непосредственно в хозяйствах и 34 кружка для повышения квалификации 500 механизаторов [4, д. 119, л. 20].

Как мы только что отметили, наряду с системой профессионального технического образования, на селе активно использовалась и такая важная фрорма массовой подготовки квалифицированных рабочих, как их непосредственное обучение в хозяйствах. В связи с этим в колхозах и совхозах ежегодно составлялись и утверждались планы подготовки кадров массовых профессий. Заслуживает внимания в этом отношении опыт колхоза «Коммунист» Тулунского района Иркутской области. В ноябре 1966 г. на совместном заседании партийного комитета и правления колхоза была разработана и утверждена программа массовой учебы колхозников. Был утвержден руководитель колхозными курсами подготовки механизаторских кадров и определен преподавательский состав из числа инженерно-технических работников колхоза. Занятия проходили систематически и квалифицированно. В 1967 г. на созданных курсах обучалось 50 трактористов, кроме того 34 человека занимались на курсах трактористов широкого профиля в филиале СПТУ № 8, организованном в селе Едогон. Непосредственно в самом училище обучалось 18 человек [7, л. 6]. Все это позволило колхозу полностью обеспечить себя квалифицированными кадрами механизаторов.

Неослабное внимание в обозначенный период времени в колхозах и совхозах уделяли кадрам животноводства. В декабре 1966 г. бюро Читинского обкома КПСС рассмотрело вопрос о работе с кадрами животноводов в колхозах и совхозах Агинского округа. Постановление областного комитета партии было обсуждено на бюро Агинского окружкома КПСС, на бюро Агинского, Дульдургинского и на пленуме Могойтуйского райкомов КПСС, а также на собраниях во всех партийных организациях колхозов и совхозов округа.

Для укрепления этой отрасли сельского хозяйства квалифицированными кадрами в 1967 г. в животноводство было направлено 286 человек, из них 247 чабанов и 36 доярок. Среди направленных было 44 коммуниста и 153 комсомольцев. За счет лучших животноводов на фермах, в чабанских бригадах дополнительно было создано 11 партийных, 13 партийно-комсомольских групп, 14 комсомольско-молодежных. В хозяйствах округа были созданы школы для повышения квалификации животноводов [3, л. 45].

Немаловажное значение в деле закрепления людей массовых профессий в колхозном и совхозном производстве имели вопросы улучшения культурно-бытовых условий жизни и труда людей, использование мер по их материальному поощрению.

Сошлемся здесь на опыт Дзержинского района Красноярского края. До середины 1960-х гг. в районе ощущался острый недостаток 
кадров механизаторов. Для обеспечения всей имеющейся техники не хватало $15 \%$, а в ряде хозяйств до $20 \%$ трактористов и комбайнеров. Из всего наличия механизаторов только 7 \% имели I и II класс. Вследствие чего была низкая выработка на каждый трактор, допускался перерасход горюче-смазочных материалов, большие затраты на ремонт и техобслуживание.

В этих условиях в колхозах и совхозах района разработали и осуществили конкретные меры по созданию условий для высокопроизводительного труда, повышению материальной заинтересованности и усилению моральных стимулов, а также улучшению культурно-бытовых условий жизни механизаторов. В этих целях в хозяйствах района был взят курс на ежегодное увеличение строительства жилья и благоустройство квартир. За 1967-1970 гг. на сооружение культурно-бытовых объектов было и израсходовано 1710 тыс. р. В колхозах и совхозах была разработана система мер по материальному поощрению. Механизаторам выделялись бесплатные путевки в санатории и дома отдыха, вне очереди продавались легковые автомобили. Только за последние три года восьмой пятилетки механизаторам за классность, экономию средств на ремонте и горюче-смазочных материалов было дополнительно выплачено 277 тыс. р. В целях улучшения условий труда в хозяйствах района было реконструировано и построено 25 гаражей, 34 машинных двора, все колхозы и совхозы были обеспечены мастерскими для ремонта техники. Для осуществления технического обслуживания машинно-тракторного парка в районе были созданы специализированные звенья мастеров-наладчиков, перешли на круглогодичный график ремонта тракторов, ремонт комбайнов производился в осенне-зимний период. Особое внимание было уделено подготовке механизаторских кадров и повышению их квалификации. В течении только 1969 г. и 1970 г. было подготовлено 482 трактористов, 23 комбайнера, 30 механизаторов животноводческих ферм, 25 шоферов и более 100 специалистов других профессий. Около 700 механизаторов повысили свою квалификацию. Все это позволило колхозам и совхозам района к 1970 г. обеспечить себя собственными кадрами механизаторов, 47 \% которых имели | и |І класс [10, л. 85].

С этой точки зрения заслуживает внимания и опыт колхоза имени Ленина Кыринского района Читинской области по закреплению кадров чабанов. Чабанский труд имеет ряд отличительных черт, в силу чего на стоянках практически невозможно создать нормальные условия для труда и отдыха. В связи с этим по решению парткома и правления колхоза все семьи чабанов были вывезены со стоянок на центральную усадьбу, чтобы дать детям возможность учиться и отдыхать в нормальных условиях. На центральной усадьбе был сооружен культурно-бытовой комплекс, удобные квартиры для жилья. Все свободное время чабаны 
проводили в деревне. На стоянках были построены уютные дома, а чтобы во время рабочей недели чабаны не чувствовали себя оторванными от жизни колхоза, района, страны в каждом домике было установлено радио, регулярно приезжали киноустановки. Эти меры позволили привлечь к работе молодежь. В 1968 г. из 113 чабанов более половины были в возрасте до 45 лет. Колхоз полностью решил проблему с кадрами этой профессии [1].

Примером создания нормальных условий для труда и отдыха животноводов является построенный в 1970 г. в Тайпинском совхозе Канского района Красноярского края молочный комплекс на 400 голов скота. В производственных помещениях было тепло, сухо и светло. Водопоение, очистка помещения, кормораздача и доение коров были полностью механизированы. Для работников ферм был оборудован красный уголок, комната отдыха, душевая, установлен телевизор и радиоприемник. Ферма была полностью укомплектована постоянными кадрами и занимала передовое место по надоям молока [9, д. 44, л. 69].

Большой вклад в дело закрепления молодежи на селе вносили комсомольские организации. Эти вопросы постоянно стояли в повестке для работы комсомольских комитетов. Например, Иркутский обком ВЛКСМ в апреле 1968 г. обсудил на пленуме вопрос «О работе комсомольских организаций по закреплению молодежи на селе». В сельском хозяйстве иркутской области работало более 6 тысяч комсомольцев. Было создано 103 комсомольско-молодежных коллектива, которые являлись наиболее распространенной формой трудового воспитания молодых тружеников. В колхозах и совхозах Красноярского края в 1966 г. работало более 20 тыс. комсомольцев, из них более 3,5 тыс. было занято в животноводстве, около 7 тыс. в полеводстве(сноска). В июне 1966 г. бюро райкома ВЛКСМ одобрило и поддержало инициативу комсомольцев-десятиклассников Усть-Абаканской средней школы Хакасской автономной области, обратившихся к выпускникам школ области, с призывом пополнить ряды молодых тружеников сельского хозяйства и остаться всем классом в родном колхозе.

С ценной инициативой выступили комсомольцы колхоза «Коммунизм» Джидинского района Бурятской АССР. В целях укрепления овцеводства кадрами, комитет комсомола направил в 1968 г. в эту отрасль 50 юношей и девушек. В целях укрепления овцеводства кадрами, комитет комсомола направил в 1964 г. в эту отрасль 50 юношей и девушек. В 1969 г. по решению Бурятского обкома ВЛКСМ в сельское хозяйство республики было направлено 1000 комсомольцев для работы чабанами, 2180 - механизаторами и 680 человек - доярками [5, л. 35].

Следующий пункт наших рассуждений о проблеме подготовки и закреплению кадров массовых профессий на селе с позиций сегодняшнего дня может показаться довольно странным. Но это исторический 
факт и не единичный, имевший распространение во всем регионе и не только. Речь идет об ученических производственных бригадах - своего рода пример приобщения к сельскохозяйственному труду со школьной скамьи с целью закрепления молодежи в селе.

Немало сельских школьников, получив в этих бригадах хорошую закалку, навсегда связали свою жизнь с профессией хлебороба, многие из них после школы окончили сельскохозяйственные вузы и техникумы. Определенный опыт в осуществлении этой работы был накоплен в Читинской области. Широкую известность здесь получили ученические бригады Малетинской, Красночикойской и Кыринской средних школ. Руководство этих школ совместно с руководителями хозяйств сообща решали задачу воспитания подрастающего поколения. За ученическими бригадами были закреплены специалисты, техника и земля. Ученические бригады не только прививали школьникам любовь к земле, но и осуществляли ценные опыты над зерновыми и овощными культурами, результаты которых помогали хозяйствам повышать урожайность полей и огородов. В 1968 г. в области работало 111 бригад, а уже весной 1969 г. их насчитывалось 183 бригады, которые объединяли 10 тыс. школьников. Во многих районах области подошли со всей ответственностью к организации бригад и созданию им необходимых условий для труда, учебы и отдыха. В Красном Чикое, например, это было предметом обсуждения на собрании партийного актива, на которое были приглашены директора всех школ. Специально созданная комиссия объехала все села, чтобы непосредственно на местах оперативно решить все вопросы, связанные с организацией производственных ученических коллективов.

В Читинском районе контроль за организацией бригад взяли на себя первый секретарь райкома КПСС Е.В. Кириллов и заведующий районо П.Н. Потехин. Они побывали во всех 27 сельских школах, где были созданы ученические бригады. Для школьников была выделена соответствующая техника и земельные площади [2].

Эта форма трудового воспитания, привлечения учащихся к производительному труду прошла проверку временем. Для многих она стала настоящей школой трудовой закалки, воспитания добросовестного отношения к труду, ориентации в выборе профессии.

В заключении отметим, что в 1970 г. в колхозах и совхозах региона работало 17,4 тыс/ специалистов с высшим и средним специальным образованием, против 12141 - в 1966 г. Качественные изменения произошли в составе кадров среднего звена. Только в Иркутской области прием в средние учебные заведения вырос с 904 человек в 1965 г. до 1107 человек в 1970 г. В течении пятилетки в колхозы и совхозы области было направлено 2798 специалистов со средним образованием. В годы восьмой пятилетки партийными организациями были приняты меры по обеспечению сельского хозяйства кадрами механизаторов. За это вре- 
мя в школах и на курсах механизаторского всеобуча Иркутской области было подготовлено 6393 человек, 7820 механизаторов повысили свою квалификацию [6, д. 27, л. 14]. В Красноярском крае всеми видами обучения было подготовлено 9620 механизаторов, 7000 трактористов машинистов повысили свою квалификацию.

Несмотря на целенаправленную работу по подготовке кадров массовых профессий в период восьмой пятилетки эта проблема решена не была. Одна из причин этого - отток механизаторских кадров из села. Так, например, в 1968 г. в хозяйства Красноярского края поступило 6178 механизаторов, а выбыло 4000 человек, в том числе 743 молодых механизаторов, окончивших сельские профтехучилища [9, д. 42, л. 110]. В основном уход из села был связан с неудовлетворенностью культурно-бытовым обслуживанием, организацией и условиями труда. С другой стороны, об этом мы говорили в самом начале статьи, этому процессу способствовало бурное промышленное развитие региона, строительство новых городов, что вызывало увеличение потребности в квалифицированной рабочей силе, которую город в основном удовлетворял за счет села.

\section{Список использованной литературы и источников}

1. Забайкальский рабочий. - 1968. - 28 янв.

2. Забайкальский рабочий. - 1969. - 21 мая.

3. Государственный архив Забайкальского края. - Ф. 3. - Оп. 16. - Д. 28.

4. Государственный архив республики Бурятия (ГАРБ) - Ф. 1. - Оп. 22.

5. ГАРБ. - Ф. 1. - Оп. 54. - Д. 810.

6. Государственный архив новейшей истории Иркутской области (ГАНИИО). - Ф. 127. - ОП. 86. - Д. 27.

7. ГАНИИО. - Ф. 273. - Оп. 20. - Д. 5.

8. Левченко В. М. Развитие материально-технической базы сельского хозяйства Восточной Сибири в 1965-1970 годы / В. М. Левченко. - Иркутский историко-экономический ежегодник: 2015. - Иркутск : Изд-во БГУЭП, 2015. C. 259-265.

9. Центр хранения и изучения документов новейшей истории Красноярского края (ЦХИДНИКК). - Ф. 26. - Оп. 44.

10. ЦХИДНИКК - Ф. 74. - Оп. 86. - Д. 10.

\section{Информация об авторе}

Левченко Владимир Михайлович - кандидат исторических наук, профессор кафедры истории и международных отношений, Байкальский государственный университет, 664003, г. Иркутск, ул. Ленина, 11; e-mail: Natalu.69@mail.ru

\section{Author}

Vladimir M. Levchenko - PhD in History, Professor of the Department of History and International Relations, Baikal State University, 11 Lenin St., 664003, Irkutsk, Russia; e-mail: Natalu.69@mail.ru 